American J. of Engineering and Applied Sciences 2 (3): 537-543, 2009

ISSN 1941-7020

(C) 2009 Science Publications

\title{
Evaluation of Liquefaction Return Period for Bangalore Based on Standard Penetration Test Data: Performance Based Approach
}

\author{
K.S. Vipin and T.G. Sitharam \\ Department of Civil Engineering, Indian Institute of Science, Bangalore India-560012
}

\begin{abstract}
Problem statement: The conventional liquefaction evaluation is based on a deterministic approach. However in this method the uncertainty in the earthquake loading is not properly taken into account. However recent research in this field indicates that this uncertainty in the earthquake loading has to be considered in the liquefaction potential evaluation. Moreover the evaluation of liquefaction return period is not possible in the conventional deterministic methods. This study explained the methods for evaluating the probability of liquefaction and the return period of liquefaction based on probabilistic approach. Approach: In this study the geotechnical data was collected from 450 bore holes in Bangalore, India, covering an area of $220 \mathrm{~km}^{2}$. The seismic hazard analysis for the study area is carried out using Probabilistic Seismic Hazard Analysis (PSHA) and the peak acceleration at ground surface was evaluated for site class-D after considering local site effects. For assessment of site class, shear wave velocity profiles in the city had been obtained using Multichannel Analysis of Surface Waves (MASW) survey. Based on this data the probabilistic liquefaction analysis was done to evaluate the probability of liquefaction in the study area. Based on the performance based approach the liquefaction return period for the study area was also evaluated. Results: The results showed the variation of liquefaction susceptibility for the study area. The corrected standard penetration values required to prevent the liquefaction for return periods of 475 and 2500 years were also presented here. Conclusion/Recommendations: The spatial variation of probability of liquefaction and the factor of safety against liquefaction evaluated using the two methods match well for the study area.
\end{abstract}

Key words: MASW, PSHA, probabilistic liquefaction, SPT

\section{INTRODUCTION}

Devastating effects of seismic soil liquefaction cases have stressed the need for assessment of liquefaction potential in seismically active areas. The simplified procedure for the liquefaction evaluation was suggested by Seed and Idriss ${ }^{[1]}$. During the past three decades this method has undergone significant modifications and a modified form of this method suggested by Youd $e t a l{ }^{[2]}$ is being widely followed for the evaluation of liquefaction potential. These conventional liquefaction evaluation methods will give the factor of safety against liquefaction. Where as a modified method, suggested by Cetin et al. ${ }^{[3]}$, will give the probability of liquefaction for any given site. However both the above methods use a single ground acceleration value $\left(\mathrm{a}_{\max }\right)$ and a single earthquake magnitude $\left(\mathrm{M}_{\mathrm{w}}\right)$ and these methods do not consider the uncertainty in earthquake loading. It has been seen from the Probabilistic Seismic Hazard Analysis (PSHA) that the frequency of occurrence of lower ground acceleration values will be more and that of the higher acceleration values will be less. This variability of ground acceleration values were not considered in the above mentioned methods. The method suggested by Kramer and Mayfield ${ }^{[4]}$ to evaluate the liquefaction return period using probabilistic method (performance based approach), the uncertainty in earthquake loading is also taken into account. This study explains the spatial variability of probability of liquefaction and the liquefaction return period of Bangalore based on probabilistic methods using SPT data obtained from 450 bore holes in an area of $220 \mathrm{~km}^{2}$.

\section{MATERIALS AND METHODS}

Probabilistic Seismic Hazard Analysis (PSHA): The study area selected is Bangalore metropolitan area, which covers about $220 \mathrm{~km}^{2}$ and is shown in Fig. 1. The seismic hazard for Bangalore at rock level was estimated using the Probabilistic Seismic Hazard Analysis (PSHA). The annual rate of exceedance of

Corresponding Author: T.G. Sitharam, Department of Civil Engineering, Indian Institute of Science, Bangalore India-560012 Tel: +91-80-23602261 Fax: +91-80-2360 2261 


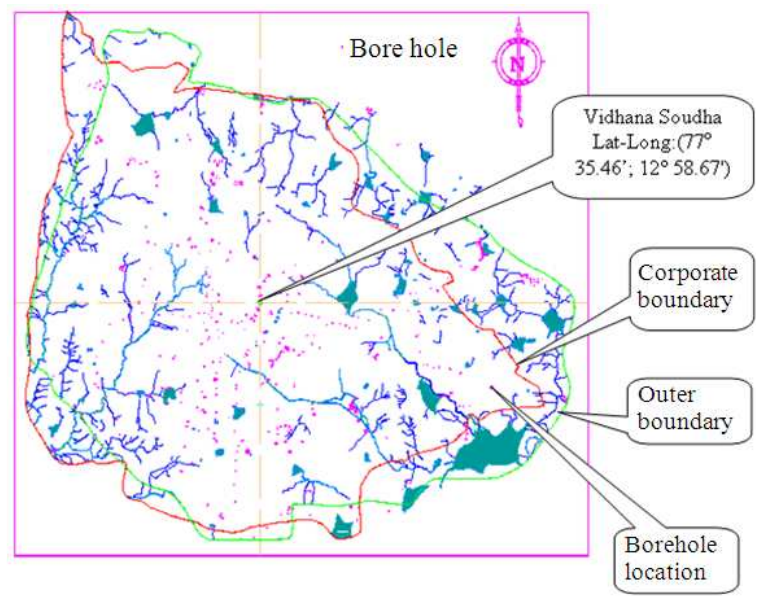

Fig. 1: Study area (Bangalore city) along with borehole locations

Peak Horizontal Acceleration (PHA) from n sources is evaluated in PSHA using the following equation:

$$
v(z)=\sum_{n=1}^{N} \sum_{m_{i}=m^{0}}^{m_{i}=m^{u}} \lambda_{n}\left(m_{i}\right)\left[\sum_{r_{j}=r_{\min }}^{r_{j}=r_{\max }} P_{n}\left(R>z \mid m_{i}, r_{j}\right)\right]
$$

Where:

$\mathrm{V}(\mathrm{z}) \quad=$ The mean annual rate of exceedance of ground motion parameter $\mathrm{Z}$, with respect to $\mathrm{z}$

$\lambda_{n}\left(m_{i}\right) \quad=$ Frequency of occurrence of magnitude $\mathrm{m}_{\mathrm{i}}$ at the source $\mathrm{n}$

$P_{n}\left(R=r_{j} \mid m_{i}\right)=$ Probability of occurrence of an earthquake of magnitude $\mathrm{m}$ at a distance $r$ from the site for a seismic source $n$

$\mathrm{P}\left(\mathrm{Z}>\mathrm{z} \mid \mathrm{m}_{\mathrm{i}}, \mathrm{r}_{\mathrm{j}}\right)=$ Probability at which the ground motion parameter $\mathrm{Z}$ exceeds a predefined value of $\mathrm{z}$ when an earthquake of magnitude $m$ occurs at a distance of $r$ from the site

In this analysis the uncertainties involved in magnitude recurrence rate ${ }^{[5]}$, hypocentral distance ${ }^{[6]}$ and the attenuation of seismic waves ${ }^{[7]}$ were considered.

While evaluating the liquefaction susceptibility, the surface level Peak Ground Acceleration (PGA) has to be calculated. The PGA values were calculated from the rock level PHA values, using the amplification factors suggested by Raghu Kanth and Iyengar ${ }^{[7]}$. To estimate surface level PGA values, the site class presented by Anbazhagan and Sitharam ${ }^{[8]}$ for the study area based on MASW survey was used. Surface level acceleration values were estimated using the attenuation relations presented by RaghuKanth and Iyengar ${ }^{[7]}$ for South India.

Probabilistic evaluation of liquefaction potential: While evaluating the liquefaction potential, the earthquake loading Cyclic Stress Ratio (CSR) is evaluated using the following expression:

$\mathrm{CSR}=0.65 \frac{\mathrm{a}_{\max }}{\mathrm{g}} \frac{\sigma_{\mathrm{vo}}}{\sigma_{\mathrm{vo}}^{\prime}} \frac{\mathrm{r}_{\mathrm{d}}}{\mathrm{MSF}}$

Where:

$\mathrm{a}_{\max }=$ Peak ground acceleration

g = Acceleration due to gravity (in the same unit as $\left.a_{\max }\right)$

$\sigma_{\mathrm{vo}}=$ Total vertical stress at the given depth

$\sigma_{\text {vo }}^{\prime}=$ Effective vertical stress at the given depth

$\mathrm{r}_{\mathrm{d}} \quad=$ Stress reduction factor

MSF = Magnitude scaling factor, which depends on the moment magnitude of earthquake

After analyzing significantly large database of field histories of seismic soil liquefaction, Cetin et al. ${ }^{[3]}$ suggested a new procedure for evaluating the probability of liquefaction potential. The relation suggested is:

$$
\mathrm{P}_{\mathrm{L}}=\Phi\left[\begin{array}{c}
\left(\mathrm{N}_{1}\right)_{60}\left(1+\theta_{1} \mathrm{FC}\right)-\theta_{2} \ln \mathrm{CSR}_{\mathrm{eq}}-\theta_{3} \ln \mathrm{Mw} \\
-\frac{-\theta_{4}\left(\ln \left(\sigma_{\mathrm{v} 0}^{\prime} / \mathrm{P}_{\mathrm{a}}\right)+\theta_{5} \mathrm{FC}+\theta_{6}\right.}{\sigma_{\varepsilon}}
\end{array}\right]
$$

Where:

$\mathrm{P}_{\mathrm{L}} \quad=$ Probability of liquefaction (as a fraction)

$\Phi \quad=$ Standard normal cumulative distribution function

$\left(\mathrm{N}_{1}\right)_{60}=$ Corrected $\mathrm{N}$ value

$\mathrm{FC}=$ Fineness content in percentage

$\mathrm{CSR}_{\mathrm{eq}}=$ Cyclic stress ratio without MSF

$\mathrm{Mw}=$ Moment magnitude of earthquake

$\sigma_{v 0}^{\prime}=$ Effective vertical pressure at the given depth

$\mathrm{Pa}=$ Atmospheric pressure (in the same unit as $\left.\sigma_{\mathrm{v} 0}^{\prime}\right)$

$\theta_{1-} \theta_{6}=$ Regression coefficients

$\sigma_{\mathrm{E}} \quad=$ Model uncertainty

Both the above methods consider a single level of ground acceleration and a single earthquake magnitude for evaluating the liquefaction potential. 


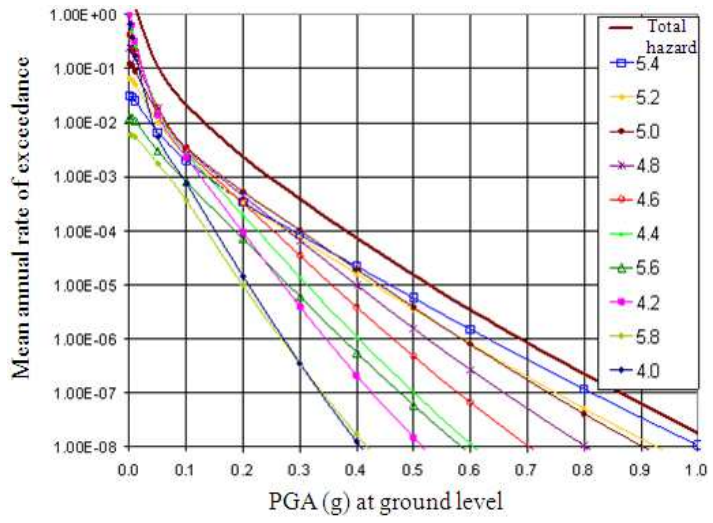

Fig. 2: De-aggregated hazard curve with respect to magnitude

Hence the uncertainty in earthquake loading is not accounted in these methods. A typical deaggregated seismic hazard curve, the variation of annual frequency of exceedance against the PHA, with respect to magnitude is shown in Fig. 2. The Fig. 2 clearly indicates that a particular ground acceleration is not contributed by a single magnitude; instead it is being contributed by different magnitudes. More over the frequency of occurrence of acceleration values also varies; lower acceleration values will occur more frequently than the higher acceleration values. These uncertainties in earthquake loading are not considered in the conventional liquefaction analysis.

Kramer and Mayfield ${ }^{[4]}$ modified the probabilistic method suggested by Cetin et al. ${ }^{[3]}$ to evaluate the return period of seismic soil liquefaction based on probabilistic approach. In this approach, the contributions from all the magnitudes and all the acceleration levels have been considered. Thus, the uncertainty involved in evaluating the earthquake loading for the initiation of liquefaction is taken care off. The annual probability of exceedance for a given factor of safety value is given by:

$\Lambda_{\mathrm{FS}_{\mathrm{L}}^{*}}=\sum_{\mathrm{j}=1}^{\mathrm{N}_{\mathrm{M}}} \sum_{\mathrm{i}=1}^{\mathrm{N}_{\mathrm{a}}} \mathrm{P}\left[\mathrm{FS}_{\mathrm{L}}<\mathrm{FS}_{\mathrm{L}}^{*} \mid \mathrm{a}_{\mathrm{i}}, \mathrm{m}_{\mathrm{j}}\right] \Delta \lambda_{\mathrm{a}_{\mathrm{i}}}, \mathrm{m}_{\mathrm{j}}$

Where:

$\Lambda_{\mathrm{FS}_{\mathrm{L}}^{*}}=$ Annual rate at which factor of safety will be less than $\mathrm{FS}_{\mathrm{L}}^{*}$

$\mathrm{FS}_{\mathrm{L}}=$ Factor of safety against liquefaction

$\mathrm{FS}_{\mathrm{L}}^{*}=$ Targeted value of factor of safety against liquefaction

$\mathrm{N}_{\mathrm{M}}=$ Number of magnitude increments

$\mathrm{N}_{\mathrm{a}}=$ Number of acceleration increments $\Delta \lambda_{\mathrm{a}_{\mathrm{i}}}$ $\mathrm{m}_{\mathrm{j}} \quad$ = Incremental annual frequency of exceedance for acceleration $\mathrm{a}_{\mathrm{i}}$ and magnitude $\mathrm{m}_{\mathrm{j}}$

The conditional probability in Eq. 4 can be evaluated by ${ }^{[4]}$ :

$$
\begin{aligned}
& P\left[\mathrm{FS}_{\mathrm{L}}<\mathrm{FS}_{\mathrm{L}}^{*} \mid \mathrm{a}_{\mathrm{i}}, \mathrm{m}_{\mathrm{j}}\right] \\
& =\Phi\left[-\frac{\left(\begin{array}{l}
\left(\mathrm{N}_{1}\right)_{60}\left(1+\theta_{1} \mathrm{FC}\right)-\theta_{2} \ln \left(\mathrm{CSR}_{\mathrm{eq}, \mathrm{i}} \mathrm{FS}_{\mathrm{L}}^{*}\right)-\theta_{3} \ln \left(\mathrm{m}_{\mathrm{j}}\right) \\
-\theta_{4}\left(\ln \left(\sigma_{\mathrm{v} 0}^{\prime} / \mathrm{P}_{\mathrm{a}}\right)+\theta_{5} \mathrm{FC}+\theta_{6}\right.
\end{array}\right)}{\sigma_{\varepsilon}}\right]
\end{aligned}
$$

Where:

$\Phi=$ Standard normal cumulative distribution

$\sigma_{v 0}^{\prime}=$ Effective over burden pressure

$\mathrm{P}_{\mathrm{a}}=$ Atmospheric pressure in the same unit as $\sigma_{\mathrm{v} 0}^{\prime}$

$$
\mathrm{CSR}_{\mathrm{eq}, \mathrm{i}}=0.65 \frac{\mathrm{a}_{\mathrm{i}}}{\mathrm{g}} \frac{\sigma_{\mathrm{vo}}}{\sigma_{\mathrm{vo}}^{\prime}} \mathrm{r}_{\mathrm{d}}
$$

$\mathrm{CSR}_{\text {eq, } \mathrm{i}}=$ The $\mathrm{CSR}$ value calculated for an acceleration $\mathrm{a}_{\mathrm{i}}$

$\mathrm{r}_{\mathrm{d}}=$ Stress reduction factor and this can be calculated using the new method suggested by Cetin and Seed ${ }^{[9]}$

In a similar way the liquefaction potential can also be characterized by liquefaction resistance required at a site for a given return period. The liquefaction resistance is characterized by SPT resistance at the given location and at the required depth. The probabilistic method can be applied to get the annual frequency of exceedance for $\mathrm{N}_{\text {req }}^{*}$ :

$\lambda_{\mathrm{N}_{\text {req }}^{*}}=\sum_{\mathrm{j}=1}^{\mathrm{N}_{\mathrm{M}}} \sum_{\mathrm{i}=1}^{\mathrm{N}_{\mathrm{a}}} \mathrm{P}\left[\mathrm{N}_{\text {req }}>\mathrm{N}_{\text {req }}^{*} \mid \mathrm{a}_{\mathrm{i}}, \mathrm{m}_{\mathrm{j}}\right] \Delta \lambda_{\mathrm{a}_{\mathrm{i}}}, \mathrm{m}_{\mathrm{j}}$

Where:

$$
\mathrm{P}\left[\mathrm{N}_{\text {req }}>\mathrm{N}_{\text {req }}^{*} \mid \mathrm{a}_{\mathrm{i}}, \mathrm{m}_{\mathrm{j}}\right]
$$$$
=\Phi\left[-\frac{\left(\begin{array}{l}
\mathrm{N}_{\mathrm{req}}^{*}\left(1+\theta_{1} \mathrm{FC}\right)-\theta_{2} \ln \left(\mathrm{CSR}_{\mathrm{eq}, \mathrm{i}}\right) \\
-\theta_{3} \ln \left(\mathrm{m}_{\mathrm{j}}\right)-\theta_{4}\left(\ln \left(\sigma_{\mathrm{v} 0}^{\prime} / \mathrm{P}_{\mathrm{a}}\right)+\theta_{5} \mathrm{FC}+\theta_{6}\right.
\end{array}\right)}{\sigma_{\varepsilon}}\right]
$$

The value of $\mathrm{N}_{\mathrm{req}}^{*}$ is the corrected $\mathrm{N}$ value required to prevent the liquefaction with an annual frequency of exceedance of $\lambda_{\mathrm{N}_{\mathrm{req}}^{*}}$. 


\section{RESULTS}

The geotechnical data for the study area were collected from 450 bore holes which were spread across the study area (Fig. 1). The depth of boreholes were up to a maximum of $35 \mathrm{~m}$ and the average depth of borehole was about $20 \mathrm{~m}$. The SPT values obtained were corrected to get the $\left(\mathrm{N}_{1}\right)_{60}$. The corrections applied to SPT values include the correction for overburden pressure, short rod length, sampler, bore-hole diameter and hammer energy efficiency. MASW survey was carried out at 58 locations (Fig. 3) in Bangalore and based on equivalent shear wave velocity obtained, the study area was classified as "site class $\mathrm{D}^{p}{ }^{[8]}$. The 6 vulnerable seismic sources in the study area, which was identified by Anbazhagan et al. ${ }^{[10]}$, were used in evaluating the seismic hazard. The PGA values at surface level were calculated for site class-D using PSHA method.

In order to consider the worst scenario for the liquefaction analysis, the water table was assumed at the ground surface. The probability of liquefaction at depths of 3 and $6 \mathrm{~m}$ for a return period of 475 years are shown in Fig. 4 and 5.

The evaluation of return period of seismic soil liquefaction was done using the Eq. 4 and 7. The curves showing the variation of factor of safety against liquefaction return period at a depth of $3 \mathrm{~m}$ for four different locations in Bangalore are shown in Fig. 6. The 4 locations selected, viz. Indiranagar, Koramangala, Hudson Circle and Hebbal are prominent places in the study area and they are located at four different regions of the study area.

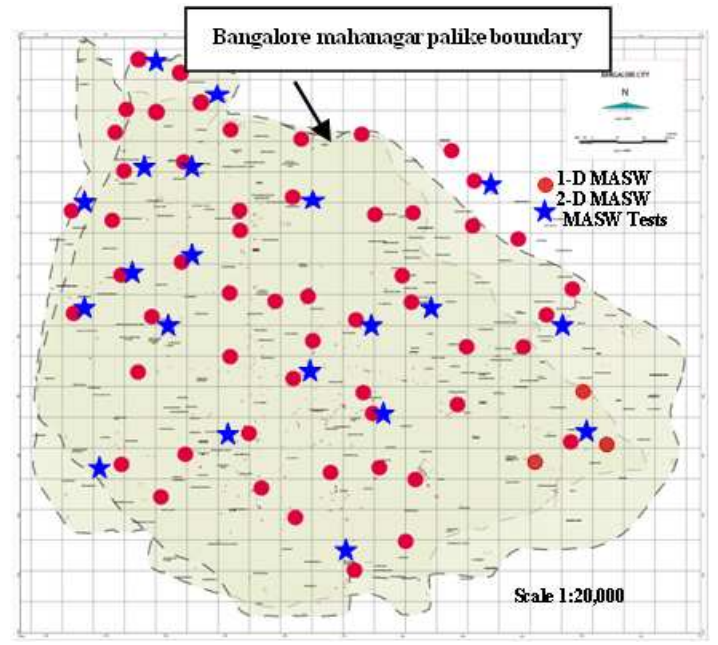

Fig. 3: MASW testing locations in Bangalore city, India
These curves are similar to the de-aggregated seismic hazard curves (Fig. 2) and both the curves show the variation of the parameters considered, peak ground acceleration or factor of safety, against the annual frequency of exceedance. The main advantages of these curves are, the factor of safety against liquefaction for any given return period can be obtained directly. Such evaluation is not possible in any of the deterministic liquefaction evaluation methods.

In a similar way, the curves between the corrected $\mathrm{N}$ values required to prevent liquefaction and return period are shown in Fig. 7. The $\left(\mathrm{N}_{1}\right)_{60}$ required to prevent liquefaction for any specified return period can be obtained from these curves. If the corrected $\mathrm{N}$ value (obtained from the site investigation) at the site is less than the value obtained from this curve, then the site is vulnerable to liquefaction for that return period.

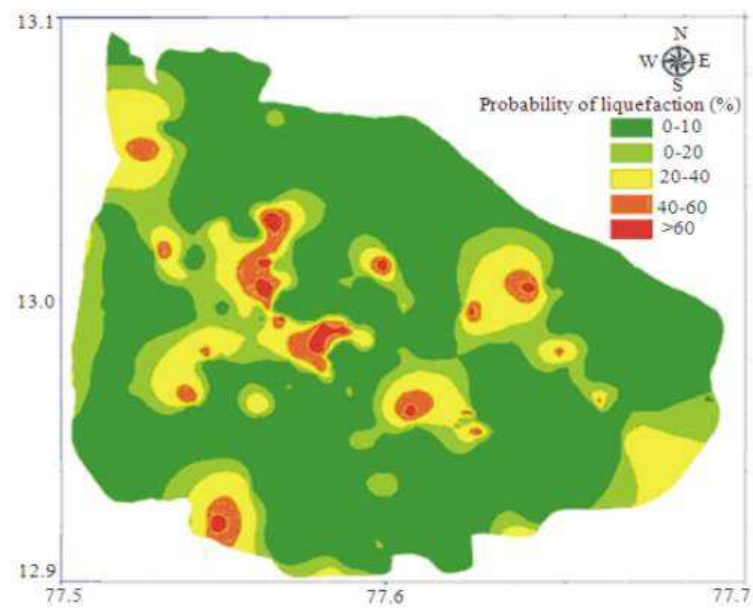

Fig. 4: Probability of liquefaction at a depth of $3 \mathrm{~m}$ for a return period of 475 years

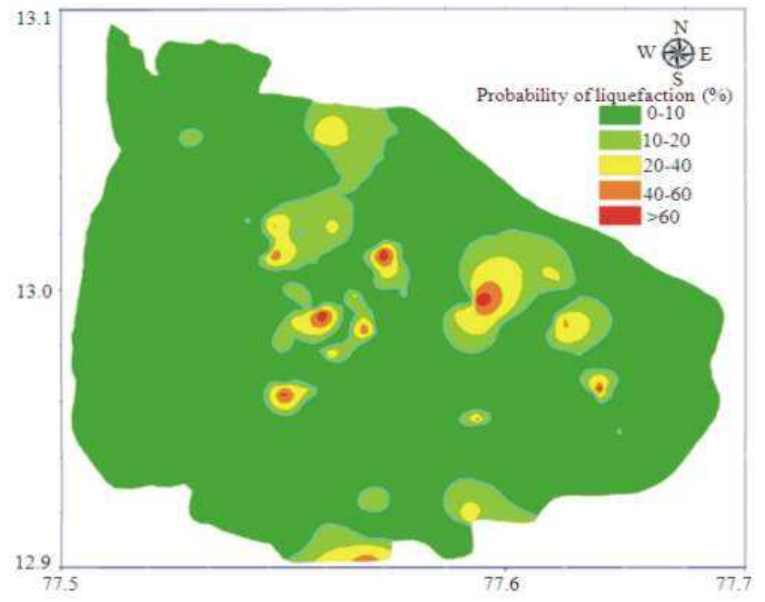

Fig. 5: Probability of liquefaction at a depth of $6 \mathrm{~m}$ for a return period of 475 years 


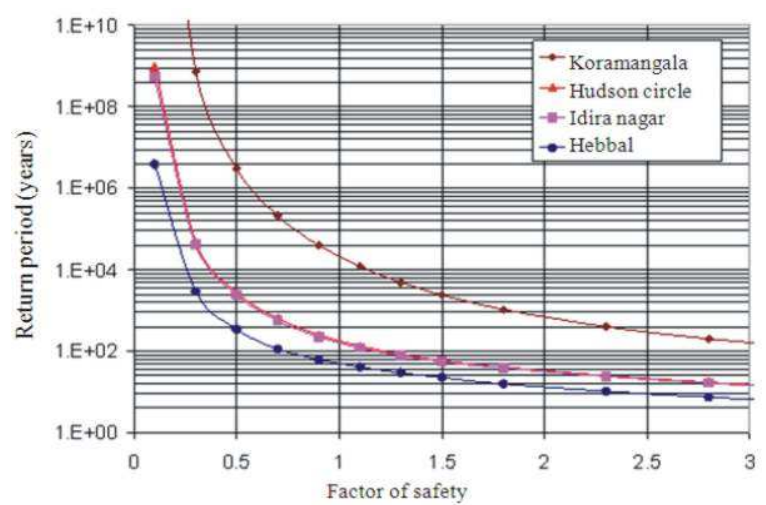

Fig. 6: Factor of safety Vs return period at $3 \mathrm{~m}$ depth for three locations in Bangalore

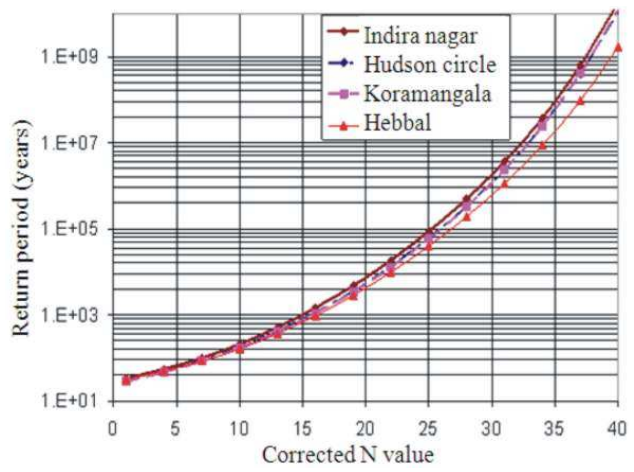

Fig. 7: $\left(\mathrm{N}_{1}\right)_{60}$ required to prevent liquefaction versus return period at $3 \mathrm{~m}$ depth for four locations in Bangalore

The variation of factor of safety against liquefaction for a return period of 475 years at depths of 3 and $6 \mathrm{~m}$ for the entire study area were evaluated and the results are shown in Fig. 8 and 9. The $\left(\mathrm{N}_{1}\right)_{60}$ required to prevent liquefaction (Fig. 10 and 11) indicate the corrected SPT values required to prevent liquefaction at the respective locations. These values increase slightly with depth, i.e., from 3-6 m, due to the increase in overburden pressure with depth.

In the recent years the building codes are revised to consider the $2 \%$ probability of exceedance of PGA in 50 years, which corresponds to a return period of 2475 years. Hence the factor of safety against liquefaction and the $\left(\mathrm{N}_{1}\right)_{60}$ required to prevent liquefaction for a return period of 2500 years were also evaluated. The factor of safety against liquefaction at depths of 3 and $6 \mathrm{~m}$ are shown in Fig. 12 and 13. The $\left(\mathrm{N}_{1}\right)_{60}$ required to prevent liquefaction at depths of 3 and $6 \mathrm{~m}$ are shown in Fig. 14 and 15.

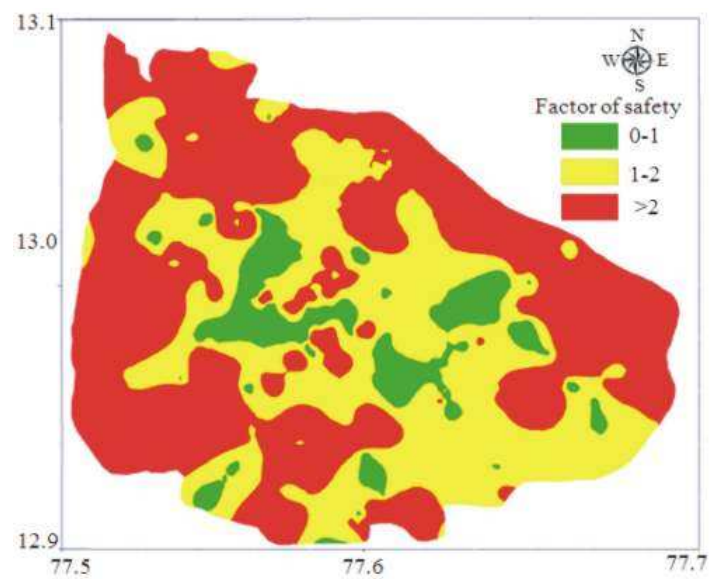

Fig. 8: Factor of safety against liquefaction for a return period of 475 years at $3 \mathrm{~m}$ depth

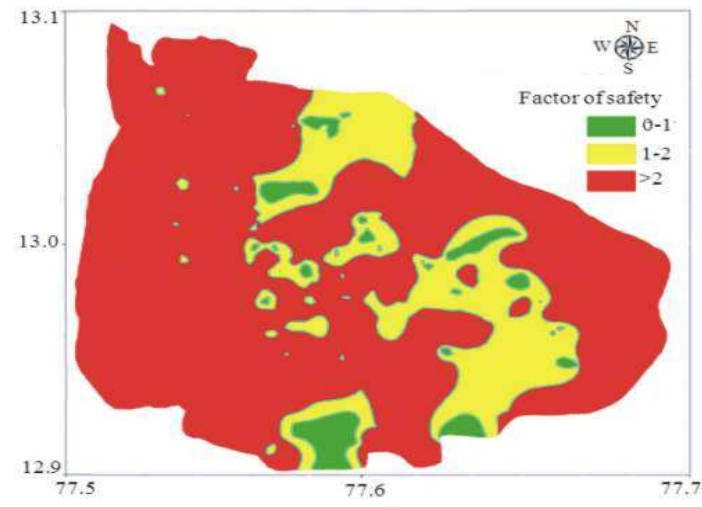

Fig. 9: Factor of safety against liquefaction for a return period of 475 years at $6 \mathrm{~m}$ depth

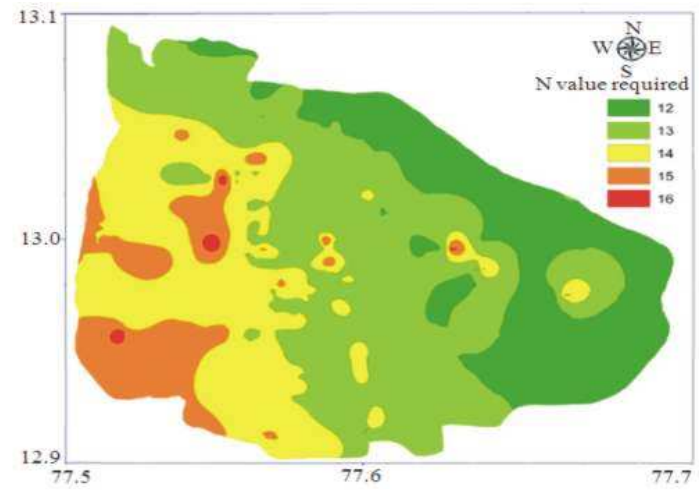

Fig. 10: $\left(\mathrm{N}_{1}\right)_{60}$ required to prevent liquefaction for a return period of 475 years at $3 \mathrm{~m}$ depth

The $\mathrm{FS}_{\mathrm{L}}$ values are showing a decreasing trend in both the Fig. 14 and 15 because of increase in return period. 


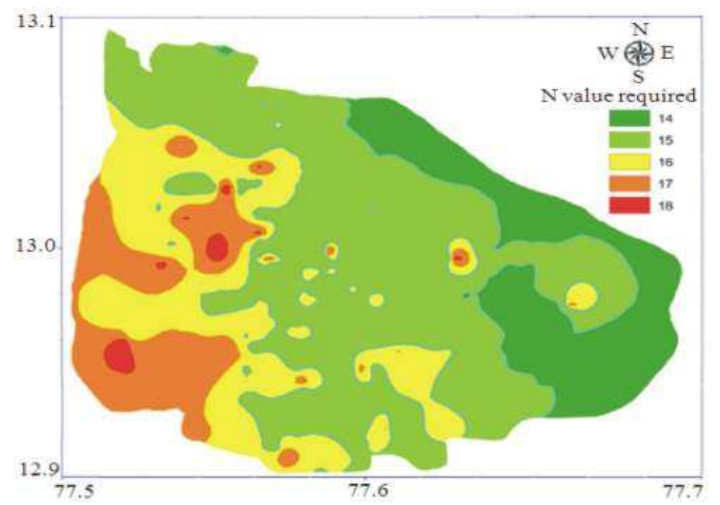

Fig. 11: $\left(\mathrm{N}_{1}\right)_{60}$ required to prevent liquefaction for a return period of 475 years at $6 \mathrm{~m}$ depth

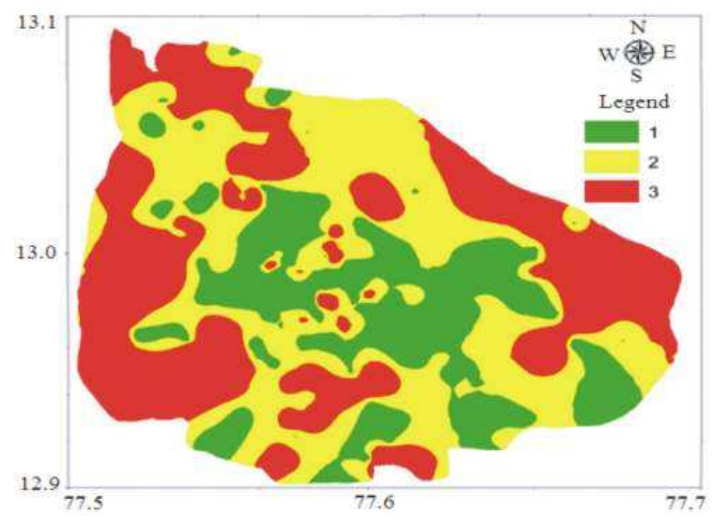

Fig. 12: Factor of safety against liquefaction for a return period of 2500 years at $3 \mathrm{~m}$ depth

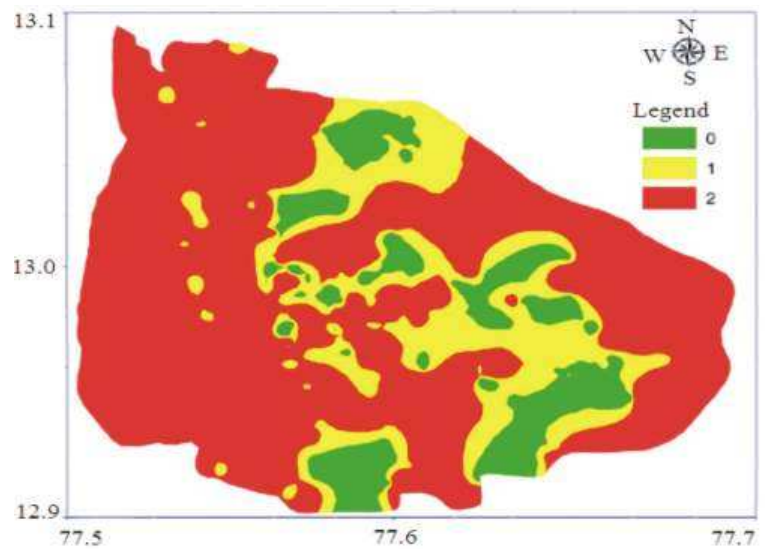

Fig. 13: Factor of safety against liquefaction for a return period of 2500 years at $6 \mathrm{~m}$ depth

The $\left(\mathrm{N}_{1}\right)_{60}$ required to prevent liquefaction also shows an increasing trend in Fig. 14 and 15 because of the increase in return period.

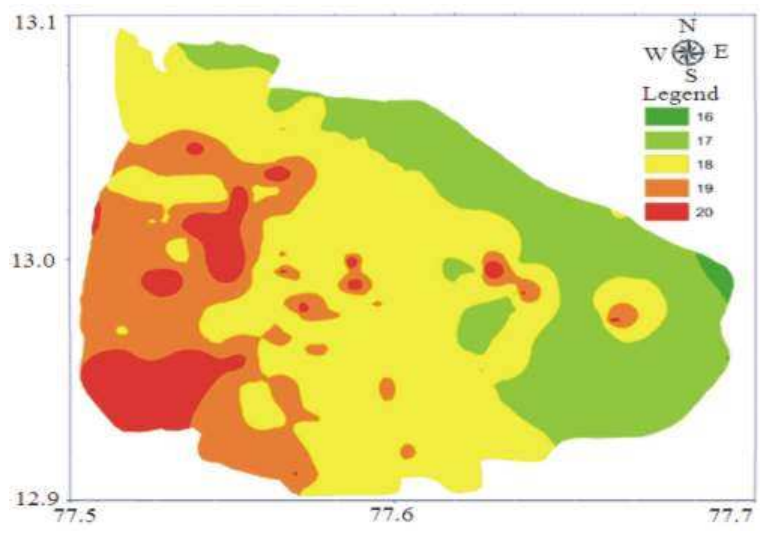

Fig. 14: $\left(\mathrm{N}_{1}\right)_{60}$ required to prevent liquefaction for a return period of 2500 years at $3 \mathrm{~m}$ depth

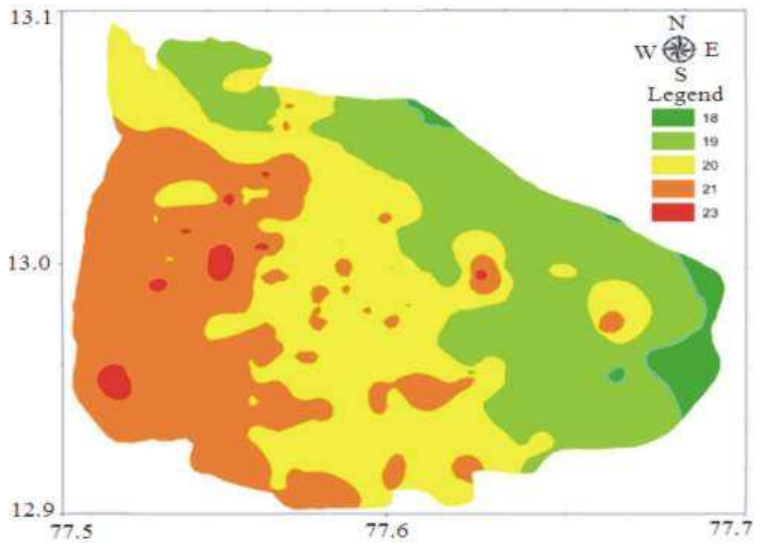

Fig. 15: $\left(\mathrm{N}_{1}\right)_{60}$ required to prevent liquefaction for a return period of 2500 years at $6 \mathrm{~m}$ depth

\section{DISCUSSION}

For the majority of the study area, the probability of liquefaction is less that $10 \%$ (Fig. 4 and 5) and these indicate that most parts of the study area are safe against liquefaction. Moreover it is clear from Fig. 4 and 5 that for most of the locations in the study area the probability of liquefaction decreases with depth. This is due to the increase in SPT values with depth for those locations.

The factor of safety (Fig. 8 and 9) range of 0-1 indicate that these locations are highly vulnerable to liquefaction; the range of 1-2 are moderately vulnerable and the factor of safety higher than 2 indicate that these locations are safe against liquefaction. At most of the locations, the factor of safety against liquefaction at $6 \mathrm{~m}$ depth is higher than that at $3 \mathrm{~m}$ depth and it is due to the increase in SPT values with depth. 


\section{CONCLUSION}

The evaluation of liquefaction potential for Bangalore was carried out based on two different methods-probability of liquefaction and the performance based approach. However the general pattern of liquefaction susceptibility matches well in both the methods. For most of the study area, the probability of liquefaction for a return period of 475 years is less than $10 \%$. The factor of safety values obtained from the performance based (probabilistic) approach show that the factor of safety values are higher than 1 for most of the study area. In evaluating the liquefaction return period using the probabilistic approach, the uncertainty in earthquake loading was taken into account in a better way than in the conventional analysis methods.

\section{ACKNOWLEDGEMENT}

Researchers thank ISRO-IISc Space Technology Cell, Indian Institute of Science, Bangalore, India for funding the project titled "Assessment of Seismicity of Peninsular India-Using Remote Sensing and GIS", (Ref. No. ISTC/CCE/TGS/195 Dated 7 March 2007).

\section{REFERENCES}

1. Seed, H.B. and I.M. Idriss, 1971. Simplified procedure for evaluating soil liquefaction potential. J. Soil Mech. Found., 97: 1249-1273. http://cedb.asce.org/cgi/WWWdisplay.cgi?7100947

2. Youd, T.L., I.M. Idriss andrus, D. Ronald, I. Arango and G. Castro et al., 2001. Liquefaction resistance of soils: Summary report from the 1996 NCEER and 1998 NCEER/NSF workshops on evaluation of liquefaction resistance of soils. J. Geotech. Geoenviron. $\quad$ Eng., $\quad 127$ : 817-833. http://scitation.aip.org/getabs/servlet/GetabsServlet ?prog=normal\&id=JGGEFK000127000010000817 000001\&idtype $=$ cvips\&gifs $=$ yes
3. Cetin, K.O., R.B. Seed, D.A. Kiureghian, K. Tokimastu, L.F. Harder, R.E. Kayen and R.E.S. Moss, 2004. Standard penetration test-based probabilistic and deterministic assessment of seismic soil liquefaction potential. J. Geotech. Geoenviron. Eng., 130: 1314-1340. DOI: 10.1061/(ASCE)10900241(2004)130:12(1314)

4. Kramer, Steven, Mayfield and T. Roy, 2007. Return period of soil liquefaction. J. Geotech. Geoenviorn. Eng., 133: 802-813. DOI: 10.1061/(ASCE)1090-0241(2007)133:7(802)

5. McGuire, R.K., 1995. Probabilistic seismic hazard analysis and design earthquakes: Closing the loop. Bull. Seism. Soc. Am., 85: 1275-1284. http://www.bssaonline.org/cgi/reprint/85/5/1275

6. Kiureghian, D.A. and A.H.S. Ang, 1977. A faultrupture model for seismic risk analysis. Bull. Seism. Soc. Am., 67: 1173-1194. http://www.bssaonline.org/cgi/search?sortspec=rel evance\&author $1=\&$ fulltext $=\&$ pubdate_year $=1977$ $\&$ volume $=67 \&$ firstpage $=1173$

7. Raghu Kanth, S.T.G. and R.N. Iyengar, 2007. Estimation of seismic spectral acceleration in peninsular India. J. Earth Syst. Sci., 116: 199-214. http://www.ias.ac.in/jess/contjun2007.html

8. Anbazhagan, P. and T.G. Sitharam, 2008. Mapping of average shear wave velocity for bangalore region: A case study. J. Environ. Eng. Geophys., 13: 69-84. DOI: 10.2113/JEEG13.2.69

9. Cetin, K.O. and R.B. Seed, 2004. Non linear shear mass participation factor (rd) for cyclic shear stress ratio evaluation. Soil Dyn. Earthquake Eng., 24: 103-113. DOI:10.1016/j.soildyn.2003.10.008

10. Anbazhagan, P., J.S. Vinod and T.G. Sitharam, 2009. Probabilistic seismic hazard analysis for Bangalore. Nat. Hazards, 48: 145-166. DOI: 10.1007/s11069-008-9253-3 